\title{
Physics of Basketball: Revisited
}

DOI: $10.3938 /$ PhiT. 23.006

\section{최 성 수}

\section{Physics of Basketball: Revisited}

\section{Seong Soo CHOI}

Talented players are known to execute physical motions that are impossible for common people without any difficulties. However, talented players can only execute those motions in accordance with the laws of natures, which are studied in various fields of science. Players can react to their body's condition and to certain environmental conditions, and then execute their shooting motions in natures' way. In this paper, the shooting motions, also called "shooting motor programs," of talented players are analyzed by using the principles of mechanics. Understanding Nature, including the motions in sports field, is important and is needed for the better human life.

\footnotetext{
저자약력

최성수 교수는 1987년 미국 노스캐롤라이나 주립대학 물리학과Chapel Hill)에서 1987년 박사학위를 받았다. 박사학위과정 동안 학교 클럽 (Carolina Martial Arts)을 조직하여 동양 무도정신을 일깨워주는 한편 과학 과 무도철학을 바탕으로, 당시의 Carolina 농구선수를 지도하여 "당 해의 가 장 발전한 선수(most improved player, David Popson)가 되게끔 하였 다. 이러한 공로로 1991년 노스캐롤라이나 주립대학의 명예사회회원으로 추 천되었다. (1378 ${ }^{\text {th }}$ Member of the Honor Society, "The Order of Golden Fleece"). 스포츠과학을 공부한 후(Department of Sports Science and Sports Psychology, UNC-Ch, 1988-1992), 박사후 연구원(Physics Department, North Carolina State University)을 거쳐, 현재 선문대학교 교수로 재직 중이다. 프랑스 국립연구소(CNRS-LAAS) 초청 연구원(2000), 미국 캘리포니아 주립대학(University of California at Berkeley, 2010)에 서 초청교수를 역임하였고, 2011년에는 (1 5) nm 금속 나노포어 제작 공 로로 나노기술혁신 장관상(Nanokorea 2011)을 수여받았다. (sscphy2010@gmail.com)
}

\author{
서 론 \\ <"Perfect Practice makes Perfect," - rather than "Practice \\ makes Perfect.">
}

일반적으로 높은 슈팅 확률을 유지하기 위하여서는, 45 도 이상으로 각도가 아주 크고 역회전이 큰 포물선 샷(high arching shot)이 되어야 한다. ${ }^{[1]}$ 슈팅동작은 눈, 무릎, 팔, 팔꿈치, 손목, 손가락 등의 근육들이, 외부 자극에 의한 시간적, 공간적 인 연속적인 부분동작의 화합으로서 이루어지는 하나의 동작패 턴이라 할 수 있다. 이러한 패턴동작은 두뇌에 입력된 "슈팅 모터프로그램"으로서 무의식적으로 행하여지게 된다.

일반적으로 무의식적인 스포츠의 모터프로그램 행위에 있어 서, ‘의식적인' 초보 단계(cognitive stage)'에서 '무의식적인, 숙 달된 단계(autonomous stage)'에 도달하려면, 대략 10 만 번 정도 또는 그 이상의 같은 동작의 반복이 필요하다. 즉 골퍼는 평균 하루 1000 번의 스윙 연습, 태권도의 경우, 하루 100 번 이상의 발차기 동작을 3 년 이상하여야 하며, 농구에서는, 미국 프로농구선수들이 어릴 때 연습하는 시간은 아침부터 저녁까지 대략 10 시간 이상을 3 년 이상한 경험이 있는 선수들이라고 한 다. 이러한 연습과정에서 집중력을 향상시켜 소위 "narrowing or channeling"을 형성하여, 어떠한 어려운 환경 및 고 스트레 스를 받는 상황에서도, 가장 안정적으로 운동 motor program 을 행할 수 있게 된다.

농구의 슈팅 모터 프로그램은 수많은 반복 동작을 통하여 패턴제작자(pattern generator)라는 "sub-routine program"을 형성하며, 외부 자극(stimulus)에 의하여 반사적으로 수행하게 된다. 따라서 오차가 적은 최상의 무의식적인 동작 수행을 위

\section{REFERENCES}

[1] Peter J. Brancazio, Sports Science: Physical laws and Optimum Performance (Simon and Schuster, New York, 1984). 


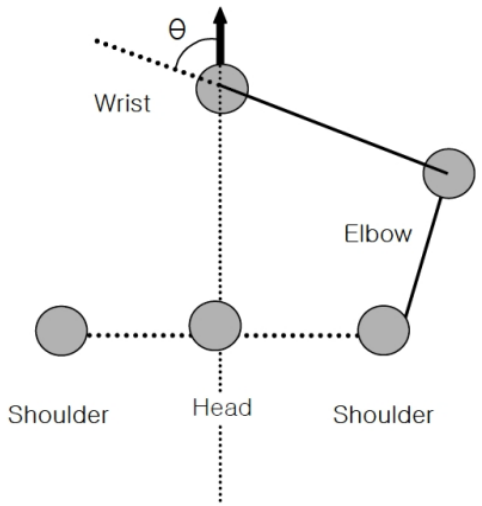

(a)

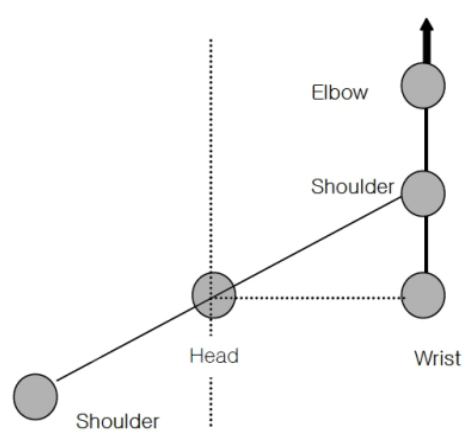

(b)
그림 1. 슈팅 자세를 머리 위에서 본 그림. (a) 공을 앞이마 위에 위치하고 슈 팅하는 자세이고, (b) 공을 어깨 쪽 팔꿈치를 자연스럽게 몸 옆 평면상으로 들 어올린 자세에서 팔꿈치(elbow)를 고정하고 팔목과 손목을 이용하는 자세. (a) 의 자세는 손목의 각도를 항상 정밀하게 위치하기가 힘들다. (b)에서 손목 (wrist)의 위치는 팔꿈치 바로 위에서 가까운 데에 위치할수록 좋다. 손목의 위 치는 일반적으로 어깨 바로 위에 위치하게 된다.

하여서는, 과학적으로 최소한 오차를 가지는 완벽한 "슈팅 모 터프로그램”을, 많은 연습으로 모터프로그램을 완성시킬 수 있 다. 즉 “완벽한 슈팅 모터프로그램, 슈팅 동작”을 수많은 연습 을 통하여 부정확도를 최소한으로 줄일 수 있을 것이다.

\section{분석 및 고찰}

\section{1. 이론적인 분석(theoretical analysis)}

슈팅 동작은 여러 동작으로 분류되며 다음과 같이 나눌 수 있겠다: 자유투(free throw shooting), 런닝 점프 슈팅(running jump shooting), 런닝 레이업(running layer-up), 몸이 바스켓 림 쪽으로 기울어지면서 팔을 바스켓을 향하여 일직선상으로 하여 손가락으로 하는 기울임 슈팅(leaner, 소위 New York leaner), 림에서 먼 쪽으로 점프하는 페이드 어웨이(fade away shot) 등으로 나누어질 수 있으나, 기본적으로 다음의 3가지 원칙을 적용할 수 있겠다.

a. 신체구조에 따른 공간의 불확실도 최소화 원칙(Minimum Uncertainty Principle I)

b. 신체동작들간의 시공간적 연결불확실성 최소화 원칙 (Minimum Uncertainty Principle II for Coordination)

c. 공에 전달된 에너지 최소화 원칙(Least Energy Principle)

서론에서 언급한 바와 같이, 최대한의 슈팅확률을 가지려면 최소한의 오차, 또는 최소 불확실도를 가진 슈팅 모터프로그램 을 행하여야 하는데, 가장 간단한 슈팅동작인 자유투와 jump shooting 자세의 경우를 설명하고자 한다.

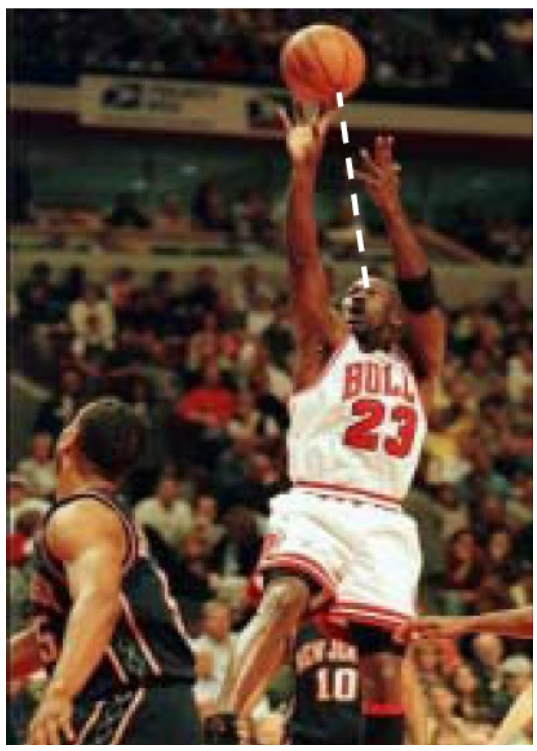

사진 1. 마이클 조던의 점프 슈팅자세: 머리, 어깨, 공의 위치가 일직선으로 되 어있음. 공을 릴리스하는 순간의 손가락을 주목할 것. 손가락 끝의 미세근육 조 직을 이용하여 공의 방향과 운동량을 조절하고 있다.

(1) 자유투 및 점프 슈팅 자세

(1) 신체구조에 따른 불확실도 최소화 원칙: 2 차원적인 슈팅 자세

우선적으로 슈팅 동작의 팔과 손목의 기하학적인 구조를 보 자. 동양 선수들의 동작은 눈과 눈 사이의 한가운데 이마 위에 농구공을 위치하고 슈팅하는 것을 볼 수 있다. 그러나 어깨의 위치, 팔꿈치, 손목의 위치를 고려하여 보면 [그림 1]에서 보는 바와 같이 3 차원적인 구조를 가지게 된다. 어깨와 팔과의 각 도, 팔꿈치의 각도, 손목과 팔목과의 각도, 즉 자유도가 3 개가 된다. 특히 팔목과 손가락과의 각도를 항상 일정하게 만들어 주어야 하는 자세는 손목 관절을 자연스럽게 조절하는 동작이 아니기 때문에 항시 불확실성을 내재한 동작이다.

반면 팔이 몸 옆과 “수평으로 되어있는 평면싱”에서 손목을 어깨 위로 들어 올려 팔꿈치를 고정시킨 뒤에 "팔꿈치 이하의 손목"까지의 부분으로 원운동을 하여 주면서 손목의 회전운동 을 하여주면 2차원적인 동작으로 된다. 더불어 검지 손가락과 팔꿈치와 일직선상으로 하여 바스켓 림을 향하는 원운동을 수 행하여야 한다. 이때의 동작은 팔꿈치와 손목을 자연스러운 일 직선상으로 움직이게 된다. 따라서 이런 전체 슈팅 동작은 어 깨 위의 평면상에서 관절의 자연스런 움직임에 따른 2 차원 운 동이 되는 것이다. 따라서 3 차원적인 동작보다는 2 차원적인 어 깨 바로 위로 팔을 들어 올리는 동작이 불확실도를 줄이는 슈 팅이 될 것이다[사진 1 , 그림 1]. 이 슈팅방법은 미국 피터 마 라비치(Peter Maravich)도 선호하는 슈팅동작이다.

또 다른 이유로서는 눈과 손목, 손가락의 조화(hand-eye coordination)라는 점이다. 초보자는 눈과 농구의 바스켓과의 정렬 


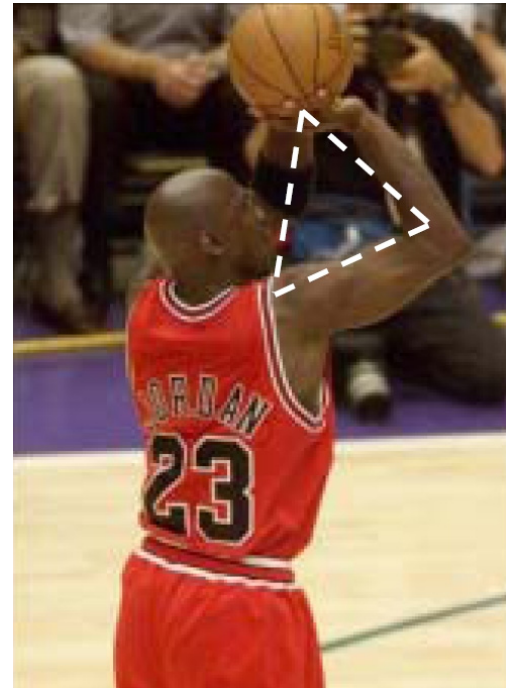

사진 2. Michael Jordan의 슈팅 자세: 어깨, 공과 팔꿈치의 위치를 주시할 것. 손바닥이 아닌 손가락만으로 공을 잡고 있다.

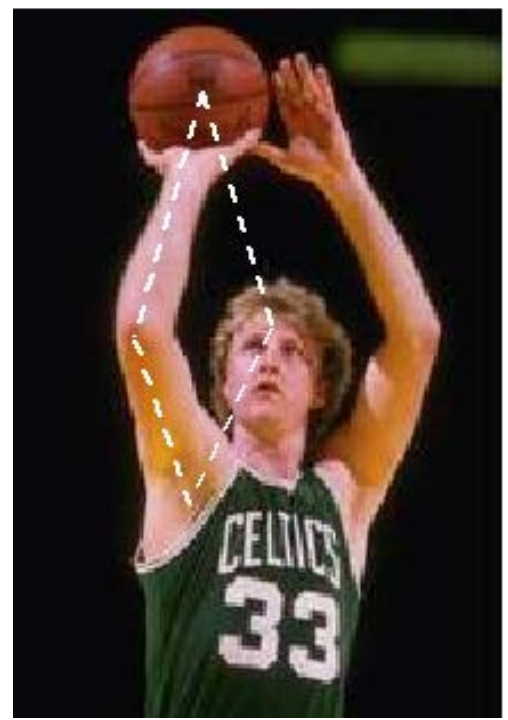

사진 3. 1980년대 NBA 팀 Boston Celtics 소속의 Larry Bird의 슈팅 자세: 상반신이 정면과 각도가 주어진 자세에서 팔꿈치를 고정시키고 공을 손가락만 으로 잡고 팔꿈치 이하의 신체부분만을 이용하여 슈팅하고 있다.

을 위하여 일반적으로 눈과 눈 사이의 한 가운데에 농구공을 위 치시킨다. 그러나 숙련된 선수 특히 미국 NBA 선수들을 보면, 몸 전체가 약간 전방과 각도를 가지고 선 상태에서, 어깨 위에 공을 위치시킨 후 손목과 팔꿈치를 펴면서 슈팅하는 모습을 볼 수 있다. 몸을 비스듬하게 서는 자세는 눈과 목표물과의 각도를 최소로 줄이기 위한 자세이다. 이와 비슷한 경우로 사격이나 양 궁, 국궁 등의 스포츠에서 눈과 손, 목표물간의 일직선으로 하는 옆으로 선 자세를 고려하면 쉽게 이해가 갈 것이다[사진 1].

[예 1] Larry Bird

완전한 슈팅모터프로그램의 무한한 연습을 통한 위대한 선수

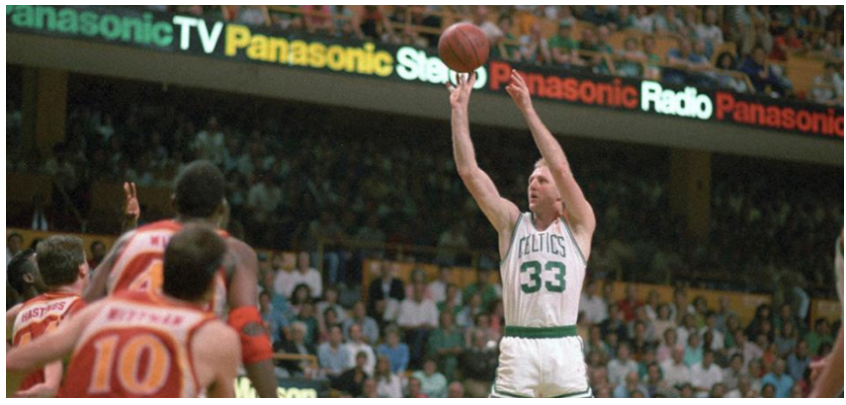

사진 4. Finger-tip roll by Larry Bird.

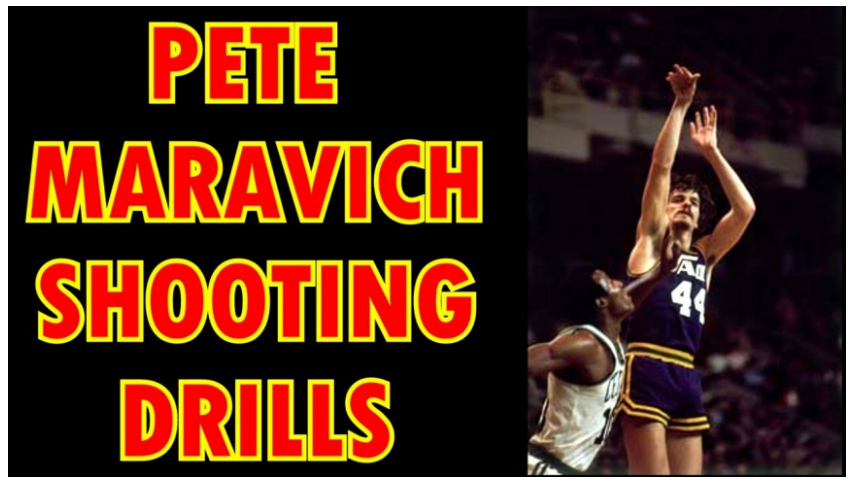

사진 5. Peter Maravich Shooting form; 〈검지손가락(index finger)을 중 심축으로 팔꿈치, 어깨, 눈 등이 거의 일직선상에 있음을 주목할 것〉.

가 된 대표적인 예로서, 70 년대 미국 백인 농구선수의 우상인 Pistol Maravich, 80년대의 Larry Bird가 있다. Larry Bird는 Indiana State 대학을 졸업하고 Boston Celtic 프로농구단에 서 활약한 백인들의 우상이다. Larry Bird는 $30-45^{\circ}$ 정도로 옆으로서, 농구공을 어깨 위로 들어 올린 자세에서 팔꿈치를 펴면서 2 차원 원운동을 하고 손가락 끝으로 공의 회전 운동과 방향을 조절한다 [사진 $2,3,4]$.

그는 미국 농구의 "백인의 3대 병" -- 3 white diseases: (i) 순발력 없고<no agility>, (ii) 동작과 동작간의 시간적, 공 간적 근육운동, 근육의 상대적 힘의 조화관계가 나쁜 것 <no coordination(temporal and phasing sequencing relationship between related muscle groups)>, (iii) 높이 뛰는 능력이 없 는 것<no jumping>--의 대명사로 알려져 있으나, 이를 극복 하기 위하여 무한한 연습 - "일 년에 8개월은 농구와 결혼하였 다"고 말할 정도로 연습광이었다. 수많은 반복 연습 및 고도의 집중력, 소위 "narrow channeling"을 통하여 본인이 원하는 능력을 개발시킨 예라고 보여진다. ${ }^{[2]}$

\section{REFERENCES}

[2] Larry Bird, Drive - The Story of My Life (Doubleday, New York, 1989). 
[예 2] Peter Maravich: 꿈은 이루어진다

(i) 팔목(wrist), 팔꿈치(elbow), 어깨(shoulder)를 일직선상으 로 하고,

(ii) 농구공을 index finger로 방향조정 및 농구 볼을 release 을 하게 한다[사진 5].

(iii) 팔꿈치를 축으로 하고 회전운동을 이용한 슈팅, 또는 팔 꿈치를 일직선으로 어깨 위로 들어 올린 후, 손목과 손가 락 끝만을 사용하는 슈팅자세이다.

Peter Maravich는 아버지가 Lousiana State University 대 학(LSU)의 코치로서 아버지와 같이 LSU에서 3년간 활약하면 서 평균득점이 40점대를 기록한 전무후무한 전설적인 농구선 수이다. 당시에는 대학 한 팀의 평균이 60점 정도이고 득점 3 점슛이 없었다. Peter Maravich는 위에 언급한 백인의 신체적 결함을 연습으로 극복하고, 5 세부터 프로농구 선수가 되기를 희망하여 백인사상 처음으로 프로농구 구단과 100 만 불에 계 약을 한 선수이다. 영화 "Pistol"이란 이야기는 이분의 전설적 인 농구선수가 되기까지의 이야기를 다룬 영화이다. 초등학교 시절 3 마일 거리 학교까지 자전거를 타고 농구공을 드리블하 면서 가고 오고를 하였고, 시속 30 마일(약 $48 \mathrm{~km} / \mathrm{h}$ )로 달리 는 자동차 안에서 도로상의 농구공을 드리블하는 연습, 비 내 리는 진흙 속에서 2 시간씩 드리블하는 연습광이기도 하였다고 한다. 더불어 검지 끝에 3 시간 이상 농구공을 회전시키는 능력 을 가졌다고 한다. 그의 어린 5 세 아이의 꿈은 백인농구사상 처음으로 100 만 불로 계약하는 선수가 되었다. 프로구단 입단 후 종교에 귀의하여 Reborn Christian이 되어 YMCA에서 농 구교육 도중 33세의 심장마비로 사망하였다. 당시 신문보도에 의하면, 특히 사망 후, 의사들의 진단 결과로 그의 신체에서 artery가 하나가 없는 것으로 판명되어 많은 사람들을 놀라게 하였다. 이러한 신체적 결함을 가지고서도 수많은 올바른 연습 을 통하여, 가장 안정적인 motor program을 어려운 상황에서 도 "narrow channeling"이라는 정신적 집중을 통하여 행할 수 있었을 것이다.

(2) 신체 각 부분들간의 힘과 시간적 연속성 불확실도 최소화 원칙

각 부분 동작들의 시간적 연속성(temporal sequence) 및 작 용하는 상대적인 힘(relative force)의 불확실한 정도에 의하여 결정되어 크게 다음과 같이 나누어질 수 있다.

\section{전체 불확실도 $\left(\mathrm{U}_{\text {total }}\right)$}

$=$ 무릎 굴신운동에 의한 불확실도 $\left(\mathrm{U}_{\mathrm{knnee}}\right)+$ 팔꿈치 직선동작 의 불확실도 $\left(\mathrm{U}_{\mathrm{elbow}}\right)+$ 팔목 회전 운동에 의한 불확실도 $\left(\mathrm{U}_{\text {forearm }}\right)+$ 손목 및 손끝 동작에 의한 불확실성 $\left(\mathrm{U}_{\text {wrist }+ \text { inger }}\right)$

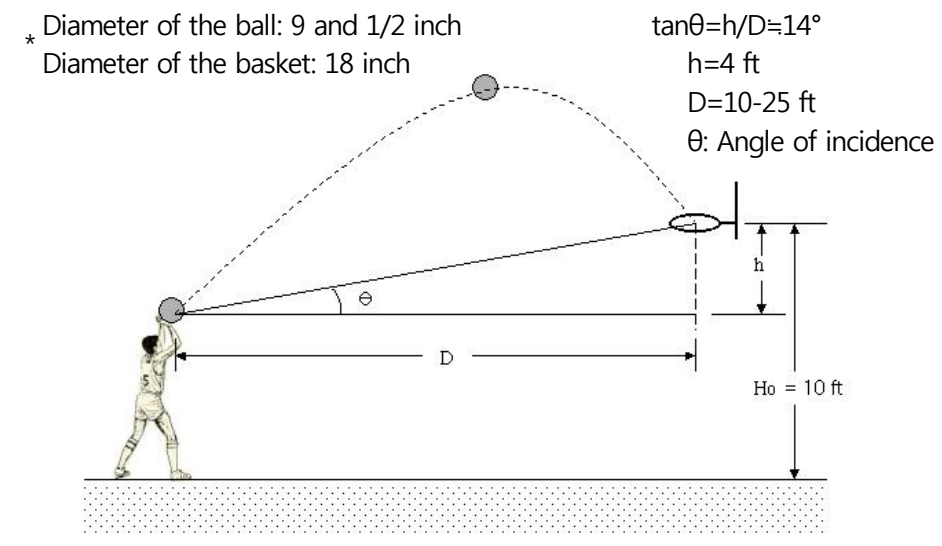

그림 2. 일반적인 농구의 기하학적인 수치: 림의 높이는 10 피트 $(3 \mathrm{~m})$, 야투 거리는 대략 10-25 피트 $(3 \mathrm{~m}-7 \mathrm{~m})$ 정도. 선수의 키를 6 피트 (약 180 $\mathrm{cm})$ 로 추정할 때 눈의 각도 $(\theta)$ 가 주어진다.

위 식에서 첫째 항은 무릎의 굴신 운동에 의한 불확실성을 의 미하며, 둘째 항은 어깨까지 팔꿈치를 들어 올리는 직선운동에 의한 것, 셋째 항은 팔목의 회전운동, 넷째 항은 손목과 손가 락 끝의 운동에 의하여 야기되는 불확실도를 의미한다. 슈팅 확률의 불확실도를 줄이기 위하여 위 4 개항의 불확실도는 각 각 최소가 되어야 한다.

슈팅에서 위의 4 가지 동작들이, 각 근육에 주어지는 상대적 인 힘의 정확성과 함께, 시간적으로 동기화된 동작(synchronized temporal sequence)으로 행하여져야 한다. 특히 자유투에서, 가급적 큰 근육조직을 사용하는 무릎운동과 팔꿈치의 직선 운 동을 분리시켜 수행하거나 제거함으로서, 불확실도를 제거하거 나 최소화함이 바람직하다.

(i) 무릎 동작이 없는 편히 선 자세에서 농구공을 팔꿈치를 어깨 위로 들어 올려 조준한다.

(ii) 공을 조준한 상태에서, 팔목의 원운동과 손목만을 사용하 여 슈팅하는 것이다.

이에 대한 실제 선수들의 분석이 그 예로써 [표 1]에 주어져 있다.

(3) 공에 전달된 에너지의 최소화 원칙(least energy principle)

농구공의 크기는 그 직경이 약 9(1/2) 인치로 주어지며 농 구 바스켓의 직경은 약 18 인치, 높이는 지면으로부터 10 피트 (약 $3 \mathrm{~m}$ )에 위치하고 있다 [그림 2].

농구공을 일정한 거리에서 바스켓에 도달하게 하는 일정량의 수평운동에너지가 필요할 것이며, 동시에 공이 가지는 전체 운 동량은 수평 방향의 바스켓까지 도달하는 '최소 수평운동량' ‘수직방향 운동량, 손목에 의한 '스핀 회전 운동량으로 나누어 
진다. 수평방향의 운동량을 최소로 조절하고 수직 상승 방향 운동량을 크게 함으로써 각도가 큰 포물선 슈팅(high arching shot)을 할 수 있게 된다. 농구 바스켓의 면벡터는 항상 수직 방향이기 때문에 농구공의 운동량 방향도 수직방향 성분이 유 효하게 작용하게 되는 것이다.

특히 인간의 근육이 슈팅 모터 프로그램을 아주 정확하게 전달할 수는 없다고 한다. 보고된 바에 의하면 약 $0.1 \%$ 의 오 차까지만 조절 가능하기 때문에, 전체 운동량이 크면 클수록 오차가 크게 생기게 된다. ${ }^{[1,3]}$ 특히 근육은 큰 근육조직(big muscle group)과 미세 근육조직(fine muscle group)으로 나누 어지는데 미세 근육 조직의 움직임만이 이러한 미세한 힘을 조정할 수 있다. ${ }^{[4,5]}$

일반적으로 초보자들, 즉 어린 아이 또는 동양권의 여자 선 수들은 약한 팔 근육의 힘을 보충하기 위하여 두 손을 이용하 는 슈팅을 하게 된다. 팔 근육을 이용한 직선 운동에너지를 이 용하고 공을 릴리스 하는 순간 두 손으로 역회전을 만들어 준 다. 이러한 경우 직선운동량이 상당히 크게 된다. 특히 농구 바스켓의 면 벡터와 수평운동방향의 운동량 벡터는 그 크로스 섹션(내적)이 0 이 되어 효율적인 방법이라고는 할 수 없겠다. 팔을 이용한 수평직선 운동량은 바스켓 근처에 도달하는 데는 초보단계에서 도움이 될 것이나 현대의 농구의 흐름 즉 키가 크고 체력과 순발력을 위주로 하는 경기에는 뒤떨어진 슈팅 방법이라고 하겠다.

\section{(4) 언더핸드 슈팅(underhand shooting)}

자연스럽게 무릎을 편 상태, 또는 가볍게 굽힌 무릎을 고정 시킨 자세에서, 팔꿈치를 자연스럽게 허리 부근에 고정시킨 다 음, 팔목 및 손목과 손가락을 이용하여 허리 아래에 위치한 공 을 손목과 팔꿈치 아래의 신체부분을 이용하여 슈팅하는 방법 이다. 어깨 아래의 상팔의 이두박근과 삼두박근의 근육을 고정 시켜 팔목의 회전운동과, 손목과 손가락에 의한 회전운동을 이 용한 슈팅동작이다. 이때 손목과 손가락의 미세근육 조직을 이 용하게 되어 최소한의 운동량을 이용하게 된다. 다른 슛 동작 에 비하여 팔꿈치 직선운동에 의한 불확실도를 제거하고, 팔꿈 치 아래부분과 손목, 손가락을 이용하여, 아주 적은 회전운동 량을 사용하기 때문에, 불확실도 원칙 (a), (b) 및 원칙 (c)를 모두 잘 만족한다.

70년대 초 Rick Barry 선수는 이 방법으로 미국 프로 농구 사상 최고의 자유투 확률 (90.4\% 이상)을 가지고 있다 [사진 6]. 최근에는 자신의 아들에게도 이 방법을 전달하여 화제가 되고 있다. 비록 Rick Barry의 슈팅에 대한 이론적인 해석은 본 저자 와는 약간 차이가 있다. 최근 미국 프로농구 스타 Lebron James의 자유투 coaching을 자원하고 나서 화제가 되고 있다.

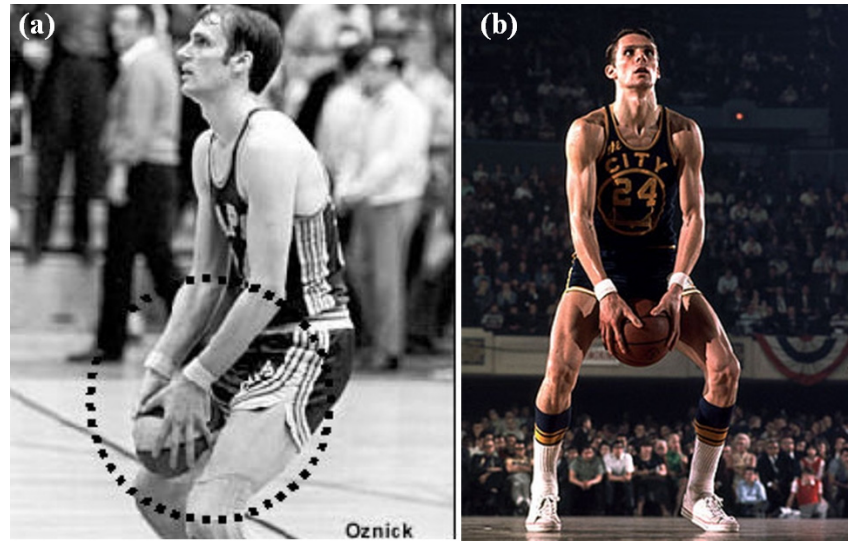

사진 6. 미국 프로 농구 사상 최대 자유투 성공률 $(90.3 \%)$ 을 가진 Rick Barry의 슈팅 자세. (1970년대 초 미국 프로농구 NBA에서 활약). 팔목과 손 목, 손가락을 이용하는 언더핸드 슈팅(underhand shooting) 자세를 취하고 있다.

\section{(5) 역회전 효과}

역회전에 의한 슈팅 확률에 대한 기여도에 대하여 정성적으 로 분석하여 보자. 자유투의 경우 종종 공이 앞부분의 바스켓 림을 맞고 바스켓 쪽으로 움직여 골인하는 경우를 볼 수 있다. 공이 아주 큰 포물선을 가지고 진행하는 공(high arching shot)의 경우 이러한 현상이 발생하며 다음과 같이 분석되어진 다.

충돌하기 전의 공은

(a) 바스켓을 향하는 수평 방향운동량이 아주 적고,

(b) 지면을 향하는 수직방향의 운동량과

(c) 매우 큰 역회전 운동량을 가지고 있다.

이를 우선 다음과 같이 두 가지 경우로 나누어 보자.

(1) 앞부분의 림을 맞는 경우와 (2) 백보드에 맞는 경우, 충돌 후에는

(a') 바스켓 림에서 멀어지는 운동량

(b') 림에서 뛰어오르는 수직방향의 운동량

(c') 역회전 운동량에 의한 림과의 마찰력은 순회전 방향의 운동량을 발생시킨다.

그림 3(a), (b)와 같이 앞부분의 림을 맞고 튀는 경우 역회전 은 림과의 마찰력에 의하여 반대 방향 순회전(forward spinning)을 하게 된다. 일반적으로 역회전은 공의 반사각을 작게 하여 주어 공이 림의 정점에 정면으로 부딪히는 경우 백보드

\section{REFERENCES}

[3] P. J. Brancazio, Am. J. Phys. 49, 356 (1981)

[4] R. A. Schmidt, Motor Control and Learning (Human Kinetics Publishers, Inc, Champaign, 1988), p. 227.

[5] S. Plagenhoef, Patterns of Human Motion (Prentice-Hall, Inc. Englewood Cliffs, 1971). 


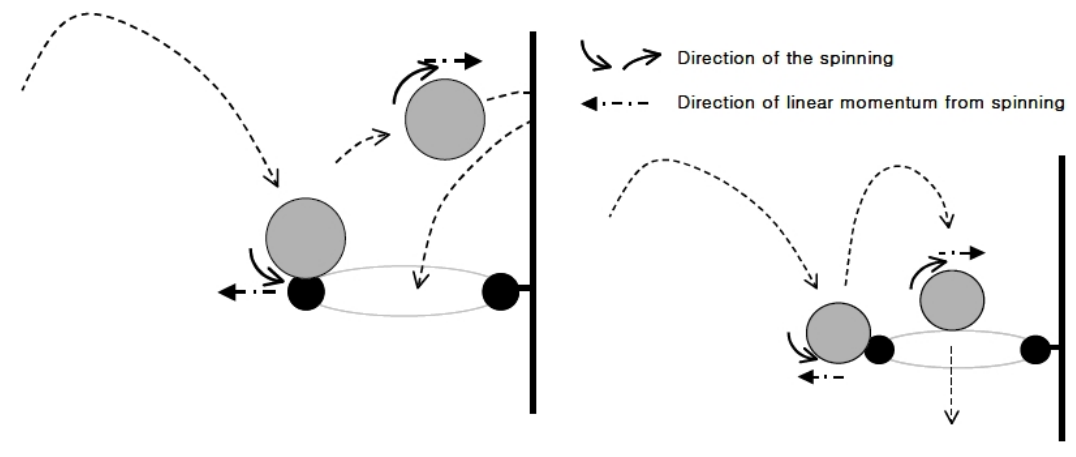

(a) (b)

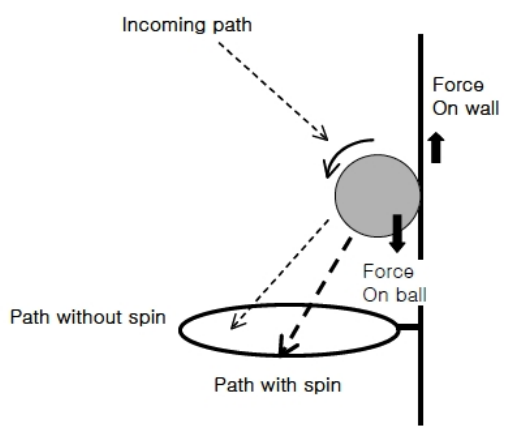

(c)

그림 3. 공이 림의 한가운데 부딪칠 때 (a), 림의 경사면에 부딪칠 때(b), 공이 백보드에 맞을 때 (c)의 백스핀의 영향. 일반적으로 공의 반사각은, 역회전이 클수록 작아져 림의 입구방향으로 반사된 공이 진행하게 만든다.

방향 쪽으로 튀게 되는데 그 반사각이 역회전의 영향으로 줄 어져 골인확률에 도움을 주게 된다 [그림 3(a)].

바스켓 림의 경사면에 부딪히는 경우에도 큰 역회전은 림과 의 마찰력을 크게 만들고, 이 마찰력이 공을 바스켓 쪽으로 밀 어주는 회전력을 발생시켜 (반대방향으로 움직이게 하는 즉 림 에서 멀어지는 (-) 수평운동량보다 크게 되면) 공은 바스켓 방 향으로 진행하여 바스켓 안으로 들어가게 된다[그림 3(b)]. 그 림 3(c)의 경우, $(-)$ 수평 방향의 운동량이 적을수록 바스켓으 로부터 멀어지지 아니하고 바로 바스켓으로 들어가게 되어 슈 팅 확률이 좋아진다. 백보드에서 접촉된 순간 공은 마찰력에 의하여 접촉면으로부터 지면방향으로 힘을 받게 되며, 동시에 순회전에 의하여 (-) 수평방향의 운동량을 줄여주면서 각도가 작게 튀어나오기 때문에 확률을 높여주게 된다.

결과적으로 다음과 같이 요약하여 말할 수 있겠다.

(i) 수평방향은 큰 운동량을 만들기도 쉬우나, 크면 클수록 전달하는 운동량의 불확실성이 크게 된다.

(ii) 수직 방향의 운동량의 불확실성은 슈팅의 정확도에 무관 하다.

(iii) 미세한 힘을 조절할 수 있는 손목과 손가락 끝의 미세근 육을 이용하여 공을 릴리스함이 필요하다.

(iv) 많은 역회전은 공의 운동량을 최소화하는데 도움이 되며 확률을 높여준다.

(2) 런닝 점프 슈팅과 레이업

실제 농구경기 중 일반 코치들이 선호하는 방법이 수비 리 바운드를 잡고 바로 속공으로 들어가 레이업 슛이나 수비가 없는 상태의 오픈 점프 샷을 하는 것이다. 이때에 빠른 속도로 드리블을 하며 달려오면서, 수평방향의 운동량을 제어함과 동 시에, 수직 상승 방향으로 뛰어 오르면서 공에 필요한 만큼의 운동량을 전달하는 데에는 어려운 문제점이 있다. 즉 몸 전체
가 움직이는 상태에서는 전체 운동량이 크고 제어하기가 힘들 어져 아주 낮은 골인확률을 기록하게 된다.

숙련된 슈터의 경우에는,

(i) 급히 달려오던 몸을 정지하기 위하여, 발뒤꿈치(heel)로 브레이크를 걸면서 엉덩이를 지면에 가까이 낮추면서 수 직 점프샷 또는 뒤로 뛰는 점프샷(fade-away shot)을 시 도한다. 이러한 동작은 뛰어오름으로서 $(+)$ 수평방향의 운동량을 완전히 없애고, 수직방향 또는 아주 느린 (-) 수평방향의 운동량을 갖게 된다.

(ii) 더불어 수직방향의 운동량이 완전히 0이 되는 순간, 즉 정점에서 막 떨어지려는 순간,

(iii) 손목과 손가락 끝만을 사용하여 농구공을 release하여 high arching shot을 만들어준다.

골 밑 레이업의 동작에서는 흔히 뉴욕린너(New York Leaner) 라고 하는 동작이 실전에 유효하다. 이 동작은 한발로 림을 향 하여 뜀과 동시에, 길게 팔을 림쪽으로 길게 펼치며 손가락 끝 을 이용하여 아주 가볍게 슈팅을 시도한다. 팔꿈치를 바스켓 림쪽으로 완전히 펴면서 손가락 끝으로 이루어지는 동작은 몸 의 상승동작이 끝나 지상으로 떨어지기 시작하는 순간, 손가락 끝으로 공을 이탈시켜야 한다(release). 이러한 경우에는 역회 전(backspin)과 옆회전(side-spin)을 상황에 따라서 이용하게 된다. 이러한 슈팅은 불확실도를 최소화하기 위하여 수직운동 량이 완전히 0이 되는 순간 손가락 끝만을(finger-tip roll) 사 용하여 아주 가볍게, 최소한의 회전운동량을 전달하게 돤다. [사진 1, 4]

(3) 훼이드 어웨이 샷(fade-away shot)

훼이드 어웨이 슈팅 동작(fade away shooting)은 일반적으 로 골(basket) 근처 부근에서 바스켓을 등 쪽으로 한 자세에서 수행하거나, 야투의 경우 수비자를 피하면서 시야를 넓혀 슛블 
표 1. 미국 동부 대서양 연안 대학 농구 리그 선수들에 대한 분석표. 7 명의 선수들 중 5 명은 아직까지 미국 NBA에서 선수로 활약하고 있으며, 일부 선수들은 현재 미국 일부 리그 대학 감독으로 활약 중이다. 7명 전부 고등학교 졸업 당시 미국 고교 졸업생 중에서 최우수선수 25명에 모두 선출되었다.

\begin{tabular}{|c|c|c|c|c|c|}
\hline Player Movements & Knee Bending & Elbow & Arm & Wrist & $\begin{array}{l}\text { Shooting } \\
\text { Percentage }\end{array}$ \\
\hline J. R. Reid & No & Moving & Linear & Little rotation & $65 \sim 70 \%$ \\
\hline Scott Williams & Yes & Fixed & Rotation & Rotation & $65 \sim 70 \%$ \\
\hline \multirow{2}{*}{ Kenny Smith } & No & Fixed & Rotation & Rotation & \multirow{2}{*}{$80 \sim 85 \%$} \\
\hline & & Perfect ti & motions & & \\
\hline Joe Wolf & No & Fixed & Rotation & Rotation & $80 \sim 85 \%$ \\
\hline \multirow[b]{2}{*}{ Danny Ferry } & No & Fixed & Rotation & Rotation & $80 \sim 85 \%$ \\
\hline & \multicolumn{4}{|c|}{$\begin{array}{l}\text { After lifting his elbow, } \\
\text { he aims at the target and release the ball }\end{array}$} & $80 \sim 85 \%$ \\
\hline \multirow{2}{*}{ Jeff Lebo } & No & Fixed & Rotation & Rotation & \multirow{2}{*}{$80 \sim 85 \%$} \\
\hline & & low moti & d after ex & & \\
\hline \multirow[b]{2}{*}{ John Smith } & No & Fixed & Rotation & Rotation & \multirow[b]{2}{*}{$80 \sim 85 \%$} \\
\hline & \multicolumn{4}{|c|}{$\begin{array}{l}\text { Isolate of arm motion, } \\
\text { fixed elbow with slow forearm rotation }\end{array}$} & \\
\hline
\end{tabular}

럭(shot blocking)을 피하면서, 슈팅을 효율적으로 할 수 있는 장점이 있음으로 많은 NBA 선수들이 행하고 있다. 골 밑 훼이 드 어웨이 샷의 경우, 한 발이 바스켓에서 먼 쪽으로 나아가면 서 발뒤꿈치를 축으로 하고 무릎과 엉덩이를 동시에 굽히면서, 바스켓으로부터 또는 수비자로부터 멀리 뛰면서 하는 동작으로 이루어진다. 이 동작은 뒤로 뛰는 속도가 앞으로 뛰는 동작보 다 느리며, 공의 릴리스 순간은 수직상승 운동량이 완전히 없 어지는 정점이 된다. 수비자로부터 멀어져 슈터의 시야를 넓혀 주는 장점, 미세 운동량을 조절하기 쉬운 장점이 있어 최소 불 확실도 원칙을 만족시킨다.

특히 이 동작의 수행에 있어서 중요한 점은 발뒤꿈치를 지 면에 부착시켜야 한다는 것이다. 따라서 대부분의 선수들의 경 우 발의 앞부분만을 이용하여 빨리 뛰는 습관을 가지고 있으 므로 또 다른 모터프로그램을 인지하여야 한다. 따라서 개인적 인 능력에 따라서는 수행하기가 용이하지 아니한 면이 있다.

\section{Video player를 이용한 분석}

본 저자는 1987년, 미국 동부의 대서양 연안 대학 농구리그 (Atlantic Coast Conference 1987)에 속하는 선수들의 슈팅동 작을 파나소닉 비디오 플레이어를 사용하여 연구하였다. 당시 녹화해둔 video film을 1초당 32 프레임이 slow motion으로 움직여 분석하였다. [표 1]에 있는 7 명의 선수들 중 5 명은 당 시 모두 미국 NBA에서 선수로 활약하였으며, 현재는 은퇴하고 몇몇 선수들은 현재 미국 일부리그 대학 감독으로 활약 중이 다. 7 명 전부 고등학교 졸업 당시 미국 고교 졸업생 중에서 최우수선수 25명(McDonald All America)에 모두 선출되었다. (i) 제이 알 리드(J. R. Reid); 선수 위치(position)가 파워포 워드(power forward)로서 자유투의 확률이 65-70\%정도 밖 에 되지 않았다. 그의 나쁜 자유투 확률은 팔꿈치를 고정시키 지 아니하고 슈팅 동작 중에 팔꿈치가 움직이는 나쁜 자세를 가지고 있고 현재 이러한 슈팅 동작을 지닌 선수로는 LA Lakers의 센터 샤킬 오닐(Shaquille O'neal)로서 그 역시 자유 투의 확률은 $50 \%$ 정도이다.

(ii) 스콧 윌리엄스(Scott Williams)는 팔꿈치를 고정시키나 처음 자세가 무릎을 구부린 매우 낮은 자세에서 눈으로 조준 한 후 나머지 동작을 완료한다. 무릎을 펴는 동작에서 조준을 비롯한 많은 불확실도를 초래하여 자유투 확률이 $65-70 \%$ 정 도에 머물렀다.

(iii) 자유투 확률이 $80 \%$ 이상 되는 대니 페리(Danny Ferry) 는 그 자세가 공을 들어 올린 후 팔꿈치를 움직이지 아니하고 림을 조준한 후 공을 팔목 및 손목, 손가락을 이용한 원운동으 로 슈팅 동작을 완료한다.

(iv) 자유투의 확률 $(85 \%$ 정도)을 가진 케니 스미스(Kenny Smith)는 팔꿈치, 팔목, 손목, 손가락의 동작들이 아주 부드럽 게 시간적(perfect temporal sequence)으로 연결되어 이루어졌 다. 후에 Houston Rocket를 NBA 우승팀으로 만든 플레이 메 이커(point guard)로서 현재는 은퇴하였다.

(v) 존 스미스(John Smith)의 동작은 일차적으로 공을 들어 올린 후 팔꿈치를 고정하고 눈으로 림을 조준한 후에, 매우 느 린 속도로 팔목, 손목, 손가락 부분의 동작을 마무리한다.

2013-2014년 현재의 노스캐롤라이나 주립대학의 power forward인 James McAdoo는 자유투 확률은 $52.7 \%$ 로서 아주 
나쁜 자유투 성공률을 가지고 있다. 그의 자유투 동작을 인터 넷 video movie를 조사하여보니, 무릎을 고정시키지 아니하고 움직이면서 슈팅을 하는 것이 확인되었다.

\section{결 론}

농구의 슈팅 동작에서 확률을 높이기 위한 각 부분 동작들, 부분 동작들의 일련화된 연속동작을 물리학적으로 고찰 분석하 여 보았다.

(i) 몸의 관절의 자연스런 움직임과 눈과 시선의 조화관계를 고려한 기하학적인 최소 불확실도, (ii) 슈팅 동작에서 사용되는 큰 근육 조직과 미세 근육조직의 오차 조절 특성을 고려한 동 작, (iii) 끝으로 최소 에너지 원칙에 따라서 볼의 진행하는 속 도가 느리고, 많은 역회전을 하고 있을 때 좋은 슈팅 확률을 가질 수 있음이 예측되었다.

따라서 물리적으로 오차를 가장 적게 만들 수 있는 슈팅 동 작을 의식적으로 반복 연습함이 컴퓨터의 서브루틴 프로그램 즉 '슈팅 모터 프로그램'을 형성하여 실제의 상황에서 슈팅 확 률을 높게 만들어 줄 수 있을 것이다. 개인적인 능력 차이에 따른 동작의 어려움과 쉬움이 존재할 것이나 슈팅의 불확실한 정도를 최소화하기 위해서는 팔꿈치를 어깨 위로 들어 올린 다음 팔꿈치를 고정시킨 자세에서 팔목, 손목 또는 손가락 근 육을 이용한 느린 동작들-적은 운동량-로 농구공을 릴리스함이 확률을 높게 할 것이다.

끝으로 무의식화된 슈팅 동작을 수행함에 있어서 가장 중요 한 요인은 호흡의 리듬에 맞추어 수행함이 높은 골인 확률을 가지게 한다는 것이다. 슛동작 중에 길게 호흡을 내쉬면 어깨 와 손의 근육을 이완시켜주고 심리적으로 안정감을 주게 되어, 미세근육의 조절이 쉬워짐이 아닐까 생각하는 바이나 아직 과 학적으로 설명된 적이 없어 재미있는 연구주제라고 하겠다.

\section{결 어}

스포츠에서 과학적인 접근을 제일 먼저 시작한 나라는 구소 련이었다. 공산주의 혁명으로 인해 노동가치설에 입각하여 영 국이나 프랑스 등의 서구에서 볼 수 있는 티타임(tea time)을 가지기보다는 체조시간을 활용하여 신체적인 발달을 도모하였 다. 1921년에 소련 전국에 150 개 이상의 스포츠클럽이 형성 되었고 6000 여 명의 체육지도자들이 훈련 양성되었다. 또한 전국적으로 GTO (Readiness for Work and Defense of the USSR)라고 하는 체육 향상 프로그램(physical fitness program)을 보급시켜 전 국민의 체력 및 신체 발달을 도모하였다 고 한다. ${ }^{[6]}$

특히 주목할 만한 것은 스포츠 지도자감독 및 코치를 포함 한)들의 양성 방법이었다. 스포츠 지도자가 되기 위하여서는 물리, 화학, 생물, 수학에 이르는 과목을 4일간에 걸쳐 입학시 험을 통과하여야 하며, 통과된 사람들은 이어서 4년 내지 5년 에 걸쳐 기초 과학 과목으로 된 힘든 과정을 이수하여야 한다 는 것이다.[6] 이러한 구러시아의 과학에 바탕을 둔 스포츠정책 은, 체력적으로 불리한 백인의 한계를 극복하고 올림픽에서 흑 인이 대부분으로 구성된 미국을 앞서는 성적을 거둔 것으로 나타났다고 한다. 구소련이 민주화가 된 후 중국은 이러한 구 소련의 정책과 스포츠과학을 받아들여 스포츠계의 급속한 발전 을 시켰다.

이러한 것을 비추어 볼 때에 스포츠를 비롯한 모든 분야에 있어서 기초 자연과학이 얼마나 중요한가를 인지할 수 있을 것이다.

\section{REFERENCES}

[6] M. Yessis and R. Trubo, Secrets of Soviet Sports Fitness and Training (Arbor House, New York, 1987), Chap. 2. 